\title{
SOSIALISASI PENGGUNAAN ALAT BRT DR SEBAGAI BAHAN BAKAR TERBARUKAN UNTUK RUMAH TANGGA
}

\author{
Oleh: Ir. Ilmardani Rince Ramli, MM.
}

\begin{abstract}
ABSTRAK
Dengan perkembangan dan peradapan manusia dengan berjalanya waktu serta perkembangan ilmu pengetahuan manusia kebutuhan hidup dan energipun berkembang kenaikan harga minyak dunia sangat berpengaruh terhadap kehidupan masyarakat indonesia. Pemerintah segera mengambil langkah mengambil subsidi bahan bakar (BBM) degan hal tersebut berdampak langsung kepada masyarakat desayang sehari harinya membutuhkan energi untuk keperluan rumah tangga.Dengan hal tersebut harus ada bahan bakar alternatif ( terbarukan)untuk solusinya dengan Tehnologi tepat guna yang efektif, efisien dan ramah lingkungan yaitu dengan membuat alat BRT DR untuk memproses limbah kotoran sapi menjadi gas untuk keperluan sehari hari bagi masyarakat untuk memasak, energi listrik sesuai dengan situasi dan kondosi lingkungan masyarakat yang mempunyai bahan dasar limbah kotoran sapi, dengan pengabdian masyarakat menggunakan alat BRT DR masyarakat sekitar candi abang, sentonorejo jogotirto berbah sleman yogyakarta dapat memanfaatkan limbah kotoran sapi utuk diproses menjadi gas degan alat tepat guna. (kata kunci : Teknologi tepat guna, BRT DR, limbah kotoran sapi, ramah lingkungan).
\end{abstract}

\begin{abstract}
With human development and developing era with the passing of time and the development of science human life and energy needs of developing any rise in world oil prices is very influential on the lives of the people of indonesia.The government immediately took steps to take fuel subsidies with the direct impact on the people of the village every day in need of energy for household needs. With this, there must be (renewable) alternative fuels for the solution with appropriate technology that is effective, efficient and environmentally friendly, namely by making a DR BRT tool to process cow manure into gas for daily needs for the community to cook, electricity in accordance with the situation and condition of the community that has the basic ingredients of cow dung waste, with community service using the DR BRT tool around the abang temple, sentonorejo jogotirto berbeman Yogyakarta can utilize cow manure to be processed into gas with appropriate tools. (keywords: appropriate technology, BRT DR, cow manure, environmentally friendly).
\end{abstract}




\section{PENDAHULUAN}

Jumlah penduduk Indonesia terus meningkat sangat berpengaruh dengan kebutuhan bahan bakar di Indonesia yang mempunyai potensi kekayaan alam cukup melimpah dari berbagai ternak . selama ini bahan baku di manfaatkan dan digunakan secara maksimal, sebagian besar peternak ataupun penduduk di pedesaan belum menerapkan tehnologi dalam pengolahan hasil dari limbah yang belum baik . Kadangkala masalah pencemaran lingkungan sekitar area peternakan menjadi bauk dan kumuh yang sangat mengganggu untuk kesehatan. Banyak peneliti hanya membuat suatu alat dan membangun instalasi biogas untuk mengolah limbah peternakan.selama ini sudah cukup banyak peternak yang sudah membangun instalasi biogas, di jawa tengah instalasi biogas semakin banyak digunakan oleh pengusaha kecil dan menengah (UKM) mendukung kelancaran usahanya.

Kotoran ternak yang ditumpuk atau di kumpulkan dalam beberapa waktu tertentu sering mengeluarkan gas methan, tetapi tidak di kumpulkan hingga gas begitu saja menguap dan mengeluarkan bau tidak sedap, dengan alat tepat guna yang akan di sosialisasikan BRT DR untuk meproses kotoran sapi menjadi gas methan selama 10 -20 hari, tergantung dengan bahan baku limbah dan metode percampuran dan fermentasi dari kotoran sapi dengan kecepatan dari alat hingga menghasilkan gas methan yang maksimal.dengan alat BRT DR ini pengisian bahan limbah kotoran sapi dimasukan kedalam alat BRT DR dengan perperbandingan $1: 1$ serta ditambah bahan untuk membantu proses permentasi yang akan lebih sempurna yang mendapatkan gas methan yang lebih banyak dan baik.

Alat BRT DR ini diharapkan untuk membantu ibu ibu pkk, ibu ibu rumah tangga dapat mengunakan secara maksimal dan bekerjasama dengan rumah wisata edukasi candi abang baik menggunakan alat BRT DR, mengumpulkan limbah kototan sapi untuk lebih efektif dan efisien yang lebih higenis untuk kesejahteraan masyarakat dilingkungan candi abang. Dan jangka panjangnya dengan mengikuti pelatihan dan penyuluhan dan sosialisasi BRT DR menjadikan lahan baru untuk usaha biogas dan pupuk cair dan padat untuk tanaman hydroponik dari limbah kotoran sapi yang selama ini hanya di buat pupuk dan membuat ligkungan kurang nyaman karena berbau, menjadi Nilai tambah ekonomi masyarakat setempat khususnya di 
lingkungan candi abang sentonorejo jogotirto berbah sleman.yogyakarta.

\section{METODE PELAKSANAAN}

a a. Peserta dalam penganbdian kepada masyarakat ini khususnya candi abang yang mempunyai ternak sapi dan ibu ibu rumah tangga , ibu ibu Pkk

b. Pengabdian .kepada masyarakat ini menggunakan metode praktek langsug yang bersifat pengarahan pemahaman proses penggunaan alat BRT DR dengan mengunakan limbah kotoran sapi. Dan awal proses sampai akhir. Dengan tahapan proses pengambilan kotoran sapi yang masih segar di campur dengan air, bahan lain di masukan kedalam alat BRT DR, proses permentasi menjadi gas methan dan menggunakan alat yang menghasilkan gas menthan untuk memasak dll.

\section{HASIL DANPEMBAHASAN}

Biogas merupakan salah satu energi alternatif yang sedang diupayakan di dusun Sentonorejo, Candi Abang. Energi alternatif ini masih belum dikembangkan dan dimanfaatkan secara luas. Di Sentonorejo, Candi Abang sendiri, instalasi biogas masih terdapat 1 plant yang berada disalah satu rumah warga. Pada saat awal pembuatan biogas tersebut mampu menghasilkan energi yang dapat digunakan secara langsung oleh warga untuk kegiatan sehari-hari. Namun demikian, proses fermentasi pada biogas harus terus dipertahankan untuk dapat menghasilkan gas yang dapat menjadi energi alternatif dalam keseharian. Ketidakseimbangan yang terjadi pada reaktor biogas dapat mempengaruhi kualitas dan kuantitas gas yang dihasilkan. Bioreaktor di Sentonorejo, Candi Abang tidak termanfaatkan lagi sejak beberapa bulan setelah bioreaktor tersebut dibuat. Pada bioreaktor yang ada di Sentonorejo, Candi Abang terdapat beberapa hal yang menyebabkan plant tersebut tidak termanfaatkan oleh warga yaitu :

\section{Plant Bioreaktor}

Di Sentonorejo, Candi Abang terdapat beberapa hal yang menyebabkan plant bioreaktor tidak menghasilkan gas yang optimal yaitu tingkat kebocoran yang tinggi pada pipa-pipa penyalur gas dan tangki penampung gas. Hal ini menyebabkan gas yang dihasilkan tidak mampu memberikan tekanan yang cukup pada penampungan gas sehingga gas tidak dapat mengalir ke rumah warga. Kebocoran ini juga yang telah menyebabkan reaktor biogas kemungkinan dapat dimasuki air yang berasal dari hujan. Proses fermentasi membutuhkan kondisi 
yang anaerob sehingga jika terjadi kebocoran, kemungkinan kondisi optimal proses fermentasi tersebut tidak tercapai, akibatnya gas yang terbentuk juga tidak maksimal.

\section{Operasionalisasi}

Untuk menjamin keberhasilan pemanfaatan limbah kotoran sapi, sangat dibutuhkan proses pengoperasian bioreaktor yang tepat. Bioreaktor harus terus diisi secara berkala pada bagian inlet dengan campuran kotoran sapi dan air yang tepat baik jumlah maupun perbandingannya. Di Sentonorejo, Candi Abang, pemahaman mengenai hal tersebut masih kurang sehingga terkadang warga memasukkan campuran kotoran tersebut dengan rasio dan jumlah yang tidak tepat. Letak plant reaktor biogas yang berada diluar ruangan terkadang juga menyebabkan plant tersebut rentan untuk mengalami kerusakan, baik disebabkan faktor bahan yang digunakan atau karena faktor lain.

\section{Gas yang dihasilkan}

Pada umumnya warga Sentonorejo, Candi Abang masih membandingkan secara langsung antara gas yang dihasilkan oleh bioreaktor dengan biogas. Meski secara kualitas gas yang dihasilkan pada biogas tidak kalah baik, namun karena jumlah yang dihasilkan tidak terlalu besar yang menyebabkan tekanan yang ada tidak cukup untuk memberikan nyala api yang besar maka warga sudah menganggap bioreaktor tersebut sudah tidak berfungsi dengan baik.Pada pelaksanaan kegiatan ini diawali dengan survey ke lokasi untuk kemudian dilakukan identifikasi penyebab tidak beroperasinya reaktor biogas tersebut. Pada kegiatan survey tersebut dilakukan analisis bersama dengan mahasiswa untuk menentukan langkah selanjutnya.

Berdasarkan hasil survey tersebut memang terdapat beberapa titik yang diduga mengalami kebocoran juga terdapat permasalahan pada penampungan gas hasil fermentasi. Oleh karena itu untuk dapat memfungsikan kembali reaktor biogas maka diperlukan perbaikan pada pipa-pipa sambungan dan penampungan gas hasil fermentasi.

Dari hasil pembicaraan dengan warga yang memiliki lahan tempat bioreaktor dibangun, disetujui perbaikan secara parsial pada beberapa bagian tersebut.Untuk menjamin keberlanjutan dari bioreaktor tersebut jugadilakukan pendampingan dan penyuluhan kapada warga yang memanfaatkan biogas tersebut. Penyuluhan dilakukan agar warga tersebut dapat 
memelihara dan memanfaatkan secara mandiri bioreaktor yang telah ada. Beberapa modifikasi yang dilakukan adalah penambahan plastik dibagian dalam dari penampungan gas, penggantian pipa-pipa yang diduga bocor, pengeleman.

\section{PENUTUP}

Kesimpulan dari kegiatan pengabdian masyarakat ini adalah :

1.Keterlibatan warga cukup baik dalam hal perbaikan dan pemanfaatan kembali biogas yang telah ada di Dusun Calok

2. Reaktor biogas telah diperbaiki dan dapat dimanfaatkan oleh warga

3.Penyuluhan sangat bermanfaat bagi warga untuk menambah wawasan dan memanfaatkan potensi lokal

\section{SARAN}

Keberlanjutan dari suatu program kegiatan pengabdian masyarakat perlu dikaji lebih jauh dan perlu peningkatan prioritas program kegiatan.

\section{DAFTAR PUSTAKA}

C. Hardian Putranto, dkk., 2010. Pelatihan Pembuatan Energi Alternatif Menuju Masyarakat Mandiri Energi dan Lingkungan Hidup yang Sehat di Desa Wukirsari Angkringan Sleman
Yogyakarta, Universitas Sanata Darma Yogyakart.

Dhe Annisa Suci, 2014. Proposal Program Kreatifitas Mahasiswa. Biokosmen (biogas kotoran sapi manfaat) di Desa Sembungharjo Kecamatan Pulokulon Kabupaten Grobogan, Universitas Negeri Semarang.

Imam Kloliq Muharom, 2015. Analisis Perencanaan Reaktor Biogasn Kap 16 M2 Dengan Pemanfaatan Kotoran Manusia Jemis Vol ; 3 No.2 Universitas ... Putro Jurusan Tehnik Mesin Surabaya Indonesia.

M.C Tri Atmodjo, . Perancangan Tangki Biogas Portabel Sebagai Sarana Produksi Energi Alternatif Di Pedesaan Balai Desa Tehnologi Pati Lampung Badan Pengharapan dan Penerapan Tehnologi.

Raldi Antono, 2017. Kuestor Proposal Limbah Sapi Untuk Biogas Dan Listrik . Sumber: Https/Koester Wardpass.Com/Bisnis/ProposalLimbah-Sapi Untuk Biogas Dan Listrik.

Suhut Simamora,dkk., 2006. Membuat Biogas Pengganti Bahan Baku Minyak Dan Gas Dari Kotoran Tanah Agromedia Pustaka 2006. Jakarta.

Y. Sulistyiyanto Dkk., 2006. Pemanfaatan Kotoran Sapi Sapi Sebagai Sumber Biogas Rumah Tangga Di Kabupaten Julang Pisau Propensi Kalimantan Tengah. Jurnal Widoyono Mengabdi. Volume 15 Nomor 2. 
